\title{
Digital Competencies and Professional Attitudes as Predictors of Universities Academics' Digital Technologies Usage: Example of Al-Hussein Bin Talal
}

\author{
Mustafa Jwaifell ${ }^{1}$, Osama M. Kraishan ${ }^{1}$, Dima Waswas ${ }^{1} \&$ Raed Omar Salah ${ }^{1}$ \\ ${ }^{1}$ Associate professor in Department of Curriculum and Instruction, Faculty of Educational Sciences at Al-Hussein \\ Bin Talal University, Jordan \\ Correspondence: Mustafa Jwaifell, Department of Curriculum and Instruction, Faculty of Educational Sciences at \\ Al-Hussein Bin Talal University, Jordan. E-mail: jwaifell@ahu.edu.jo; jwaifell@hotmail.com
}

Received: October 11, 2019

Accepted: November 12, 2019

Online Published: November 13, 2019

doi:10.5430/ijhe.v8n6p267

URL: https://doi.org/10.5430/ijhe.v8n6p267

\begin{abstract}
Information Communication Technologies (ICT) has experienced remarkable development and changes provoked by the spread of digitization and the rise of electronic technologies. Those changes raised the significance of understanding academics' perceptions and professional usage of those technologies in higher education. To understand the academics' perception of digital technologies in higher education, we have conducted this study in Al-Hussein Bin Talal University (AHU) as an example of academics' digital competencies, professional attitudes, and professional application of digital tools, in addition to exploring the possibility of predicting the degree of applying digital tools through examining the degree of academics' competencies and professional attitudes. This study as carried out in Ma'an, a poor-environment area of Southern Governorate in Jordan, with 107 academics who work in AHU as instructors, aimed to explore how they perceive new digital technologies. The most important result of the study showed that academics' competences, attitudes, and their usage of digital technologies tools are in average level. Moreover the study showed that the degree of using digital technology tools can be predicted through the degrees of the academics' competences and attitudes. Recommendations were included in this study.
\end{abstract}

Keywords: academic usage, digital technologies, ICT, competencies, attitudes, higher education

\section{Introduction}

Educational policy makers emphasized the necessity of using Information Communication Technologies (ICT) and how they should be reflected in teachers and academics' field of practice. For example, The Ministry of Education in Jordan requires that teachers receive the International Computer Driving License (ICDL) to be promoted, as well as university academics who seek higher ranks.

Information literacy for instance has been one of the main interests of scholars in the United Kingdom, where institutions needed to place a greater value on digital literacy in the education sector and prepare their students and organizational processes to thrive in an age of digital knowledge practice (Littlejohn, Beetham \& McGill, 2011). while scholars in Jordan interested in investigating information literacy for the students at the university level (Bani Abdelrahman, Jwaifell, and El-Subhieen, 2014) beside school teachers as investigating information literacy (Al-Atyat \& Jwaifell, 2014) or using innovative technology such as interactive boards (Jwaifell \& Gasaymeh, 2013). Other studies investigated Social Network Sites uses and intensity among university academics and their students (Jwaifell, Al-Shalabi, Andraws, Awajan, \& Alrabea, 2013; Al Doghmi, Al-Shalabi, Jwaifell, Andraws, Awajan, \& Alrabea, 2013; Swidan, Al-Shalabi, Jwaifell, Awajan, \& Alrabea, 2013), as well as investigating the role of using digital technology in the field of universities electronic management in achieving organizational excellence at AHU (Waswas, Jwaifell, 2019). All of these researches have been conducted with respect of digital competencies to assure the digital technologies usages. But still there is little information about academics' digital competencies, professional attitudes, professional application of digital tools, and the possibility of predicting the degree of applying digital tools through identifying the degree of academics' competencies and professional attitudes. Therefore, this study came to shed light on the aspect of digital technologies at AHU.

Learning how to use digital technologies is very essential for both academics and their students at universities. It is obvious that AHU started to use technologies very early after it had been separated from Moutah University in 1999. 
Students of AHU for instance have to register and choose their courses through the Learning Management System (LMS) on the internet. AHU's LMS contains digital tools for electronic learning uses through which academics and their students can interact with each other, besides the massive electronic courses used by students without the need for being in lectures room, since such courses are taught only online.

In AHU, the administration has greatly developed its website to abandon the paper work even for students, as their Portal allows them to have their own E-mail, download study plans, access the library, accumulate their rate, and answer questions, in addition to other pages that help them with their life in the university.

Figure 1 shows a screenshot of the students' gate:

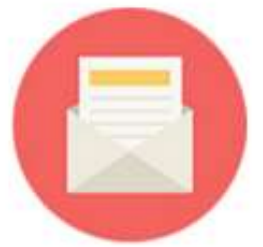

E-mail

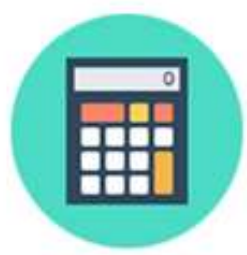

Cumulative Rate Calculator

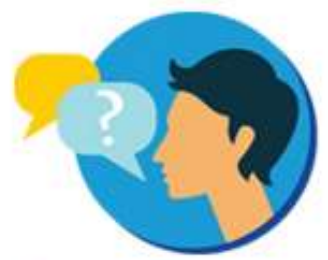

Student Information

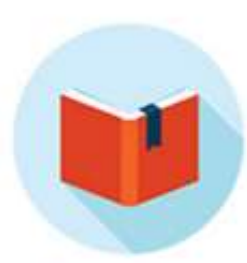

Study Plans

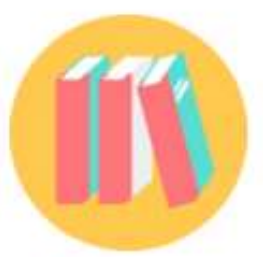

The library

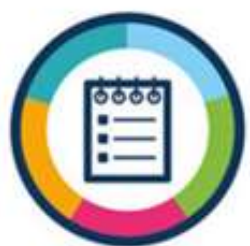

Electronic registration

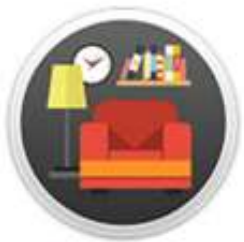

Student life

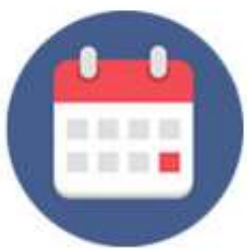

University calendar

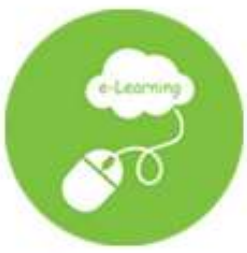

E-Learning

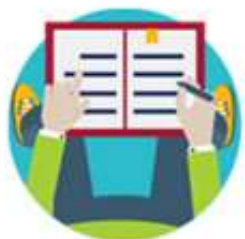

Ouarterly Courses Schedule

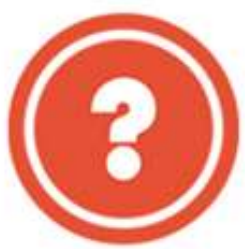

Frequently Asked Duestions

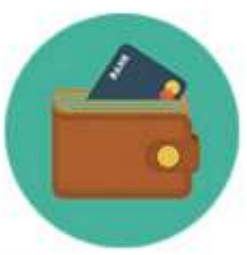

Grants and loans

Figure 1. Students gatelEnglish-Version (http://www.ahu.edu.jo/)

Students at AHU can use this website to fulfill most of his needs throughout his academic life at the university even if he needs to apply for grants. Also the E-Learning portal can give the opportunity for both students and academics to interact with each other synchronously or asynchronously in an electronic environment for the purpose of achieving any course goals. Many courses are designed and created at the AHU E-Learning Portal, where students can $\log$ in by a username and a password, some courses can give entry permission for guests to gain access to the these courses. 

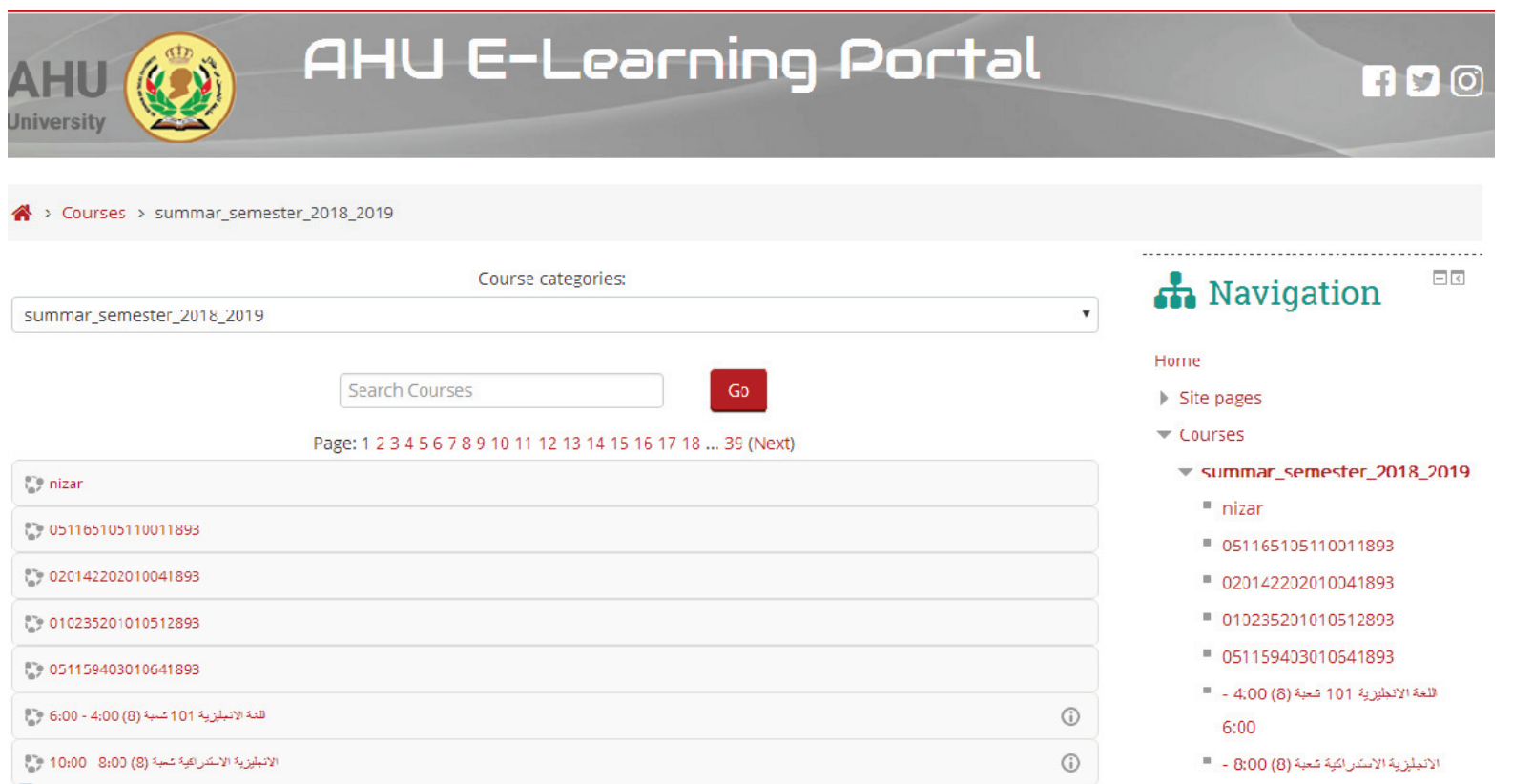

Figure 2. E-Learning courses for summer semester|English-Version (http://www.ahu.edu.jo/)

The E-Learning Portals provide instructors with limited digital tools to develop their own courses. This may include uploading texts with more than one format, sounds, and videos. Uploading those types and formats of courses content needs minor skills (competences) for using digital technologies in this aspect.

Knowing that AHU has nine collages: Art, Educational Sciences, Law, Science, Engineering, Information Technology, Business and Economics, Tourism and Archaeology, and Nursing and Health, there are only (757) courses available at the Portal, while many other courses are still not electronically designed. Though there are (345) instructors, e-learning courses do not reflect the number of Academics and Courses taught in AHU, which turns researchers' attention to examining the reasons behind this situation. In spite of having the Faculty Developing Centre which shifts a great attention to developing academics to acquire all the need skills that reflect competencies in digital literacy.

It is obvious that human beings in general take action for a stimulus if they have the attitude and the competencies they need which can be marked as a theory of action. Theory of Action is an approach that begins with the conception of human beings as designers, while theory in use can be described as theory in action which means action in use (Argyris, 1992). To gain understanding of academics' digital competencies, professional attitudes, and professional application of tools, this study is based on the work of Madsen, Thorvaldsen, and Archard (2018) and the questionnaire used in their study, beside the fact that if there is a relationship between competencies and attitudes, it is hopefully to predict the usage of digital technology among AHU academics .

\subsection{Statement of the Study Problem and Questions}

The study's main concern is to investigate the degree of academics' digital competencies, attitudes toward digital tools, the degree of using these tools for the purpose of teaching their courses, and the possibility of predicting the degree of using digital tools through the degree of academics' competence and attitude at AHU by answering the following questions:

1. Are there statistical differences at $(\alpha \leq 0.05)$ between the observed and the predicted values of academics who useldon't use e-learning in teaching courses according to faculty at AHU?

2. What is the degree of AHU academics' professional competence, attitudes, professional application of digital tools?

3. Are there statistically significant differences at $(\alpha \leq 5.05)$ between the means of academics' degrees of professional competence, professional attitudes, and professional application of technology tools according to their years of experience? 
4. Are there statistically significant differences at $(\alpha \leq 5.05)$ between the means of academics' degrees of professional competence, professional attitudes, and professional application of technology tools according to their academic rank?

5. Is it possible to predict the degree of academics' digital technologies usage in teaching through the degree of professional competence and attitudes at AHU?

\subsection{Significance of the Study}

The current study is determined by the following aspects:

- The study focuses on academics' use of technology tools in teaching at AHU, considering that the use of those technologies is one of the most important strategies for teaching students in AHU as it has become a need because of the growing number of students in AHU, beside the importance of those technology tools which can give the students more opportunities to have better understanding of the skills that they are going to gain.

- The study results may provide AHU academics with a comprehensive view of the related technologies they can benefit from in teaching their students.

- This study presents a set of recommendations that may contribute to the development and enhancement of implementing digital technologies among academics.

- Developing academics' competencies and attitudes of digital technology tools to assure implementing it in teaching.

\subsection{The Study Objectives}

The study aimed to:

1. determine the degree of academics' competencies, attitudes, and digital technologies tools usage in AHU.

2. recognize if there are statistically significant differences at $(\alpha \leq 5.05)$ between the means of academics' competence, attitudes, and digital technology tools usage according to the variables of years of experience, collage, and rank.

3. identify the possibility of predicting the degree of academics' digital technologies usage in teaching through the degree of professional competences and attitudes at AHU.

\section{Method}

An analytical methodology was used to develop the study tool, and the descriptive methodology was used to determine the degree of academics' professional competences, attitudes, and professional digital technologies usage according to the variables: using e-learning, rank of academics, and years of experience: 1-5 years, 6-10 years, more than 10 years. Regressing analyses was used to predict the degree of academics' digital technologies usage in teaching through the degree of professional competence and attitudes.

\subsection{The Study Population and Sample}

The study population consisted of (345) academics working as instructors at AHU distributed on nine faculties: Art (69), Educational Sciences (46), Law (7), Science (52), Engineering (57), Information Technology (28), Business and Economics (43), Tourism and Archaeology (18), and Nursing and Health (25). The questionnaire was distributed to all members of the faculties who work as instructors, only (107) of them responded to the questionnaire which represent $(31 \%)$ of the population, while others were not present in the university especially the study was conducted during the summer semester. The following table shows the distribution of the study sample according to the demographic variables: 
Table 1. The study population and its sample

\begin{tabular}{|c|c|c|c|c|c|c|}
\hline $\begin{array}{c}\text { Years of } \\
\text { Experience }\end{array}$ & Faculty & Instructor & Assistant Prof & Associate Prof & Professor & Sum \\
\hline \multirow{2}{*}{$1-5$} & Humanities & 6 & 5 & 0 & 0 & 11 \\
\hline & Sciences & 6 & 12 & 0 & 0 & 18 \\
\hline \multicolumn{2}{|c|}{ Sum } & 12 & 17 & 0 & 0 & 29 \\
\hline \multirow{2}{*}{$6-10$} & Humanities & 6 & 7 & 13 & 2 & 28 \\
\hline & Sciences & 8 & 4 & 4 & 1 & 17 \\
\hline \multicolumn{2}{|c|}{ Sum } & 14 & 11 & 17 & 3 & 45 \\
\hline \multirow{2}{*}{ More than 10} & Humanities & 5 & 3 & 8 & 3 & 19 \\
\hline & Sciences & 0 & 3 & 6 & 5 & 14 \\
\hline \multicolumn{2}{|c|}{ Sum } & 5 & 6 & 14 & 8 & 33 \\
\hline \multirow{3}{*}{ Total } & Humanities & 17 & 15 & 21 & 5 & 58 \\
\hline & Sciences & 14 & 19 & 10 & 6 & 49 \\
\hline & & 31 & 34 & 31 & 11 & 107 \\
\hline
\end{tabular}

\subsection{Ethics}

The study as a whole was approved by Al-Hussein Bin Talal University Research Ethics Committee at the Faculty of Education. All participants were treated as anonymous by asking them not to mention or write their names or signatures on the questionnaire.

\subsection{The Study Tool}

The study tool was based on the tool used by Madsen, Thorvaldsen, and Archard (2018) which were modified according to the common types of software used by and available for academics in the computer centre which is responsible for providing it and managing all learning Management System at the university. The tool of the study consisted of two sections: the first section included a demographic description of the study members and one question about if the academics use e-learning in teaching courses or not, the second section consisted of the items that reflected Digital Competence (familiarity with digital tools, confidenceleasiness of using digital tools, appropriateness for the subject matter, and overcoming difficulties while using digital tools), Professional Attitude ( added value, essentiality for teaching, and moderate of societylacademic-debates expectations), and Professional Application of Digital Tools (tools of: assessments, management, presentation as PowerPoint, spreadsheets as Excel, film production software, online discussionlmeeting, websites production, screen capturing, scientific analyses programs, student response systems, tools for collaborative e-writing as Google docs, social media as Facebook, and internet as a source of knowledge).

\subsubsection{The Validity and Reliability of the Measurement Tool}

The validity of the tool was verified in two ways: the first was validated by six referees of academics from different universities other than AHU, all their remarks were taken and accommodated as they recommended, while the indicators of constructive (concept) validity was confirmed by using Pearson's correlation between the items and each section of the questionnaire as shown in the following table which were very high:

Table 2. The constructive validity indicators of the measurement tool $(\mathrm{N}=107)$

\begin{tabular}{|c|c|c|c|c|c|c|c|c|c|}
\hline \multirow{2}{*}{ 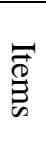 } & \multirow{2}{*}{$\begin{array}{l}\begin{array}{l}\text { Professional } \\
\text { Competence }\end{array} \\
\text { Correlation }\end{array}$} & \multirow{2}{*}{$\overrightarrow{\overrightarrow{\mathbb{\theta}}}$} & Professional & \multicolumn{6}{|c|}{ Professional Application of Digital Tools } \\
\hline & & & Correlation & Items & Correlation & Items & Correlation & Items & Correlation \\
\hline 1 & $0.89 * *$ & 6 & $0.88 * *$ & 11 & $0.78 * *$ & 17 & $0.82 * *$ & 23 & $0.77 * *$ \\
\hline 2 & $0.87 * *$ & 7 & $0.86^{* * *}$ & 12 & $0.67 * *$ & 18 & $0.77 * *$ & 24 & $0.72 * *$ \\
\hline 3 & $0.85^{* *}$ & 8 & $0.78 * *$ & 13 & $0.82 * *$ & 19 & $0.74 * *$ & 25 & $0.79 * *$ \\
\hline 4 & $0.92 * *$ & 9 & $0.77 * *$ & 14 & $0.84 * *$ & 20 & $0.74 * *$ & 26 & $0.87 * *$ \\
\hline \multirow[t]{2}{*}{5} & $0.84 * *$ & 10 & $0.75^{* *}$ & 15 & $0.77 * *$ & 21 & $0.78 * *$ & & \\
\hline & & & & 16 & $0.75^{* *}$ & 22 & $0.69 * *$ & & \\
\hline
\end{tabular}

$* *=$ Sig at $\alpha \leq 0.01$ 
The reliability of the tool was verified during applying the study by calculating the coefficient of internal consistency (Cronbach's Alpha) between the items of each section and the total items. The reliability coefficients of the study instruments were high; their internal consistency is high and was considered suitable for this study.

Table 3. The reliability of the measurement tool $(\mathrm{N}=107)$

\begin{tabular}{ccc}
\hline Sections & Items Number & Cronbach's Alpha \\
\hline Professional Competence & 5 & 0.87 \\
Professional Attitudes & 5 & 0.85 \\
Professional Application of Digital Tools & 16 & 0.88 \\
\hline
\end{tabular}

$$
* *=\text { Sig at } \alpha \leq 0.01
$$

\subsubsection{The Study Tool Scale}

The data was collected from academics' viewpoint on five likert scale for each item that reflected both digital competence and professional attitudes ( $1=$ strongly disagree, $2=$ disagree, $3=$ neutral, $4=$ agree, $5=$ strongly agree), while the items of professional application of digital tools scaled: 1=never, $2=$ rarely, $3=$ occasionally, $4=$ often, and $5=$ extensively). The scores of the study tool were divided into three categories; for the purpose of judging the degree of academics' competence and attitude as: low $=1-2.33$, average $=2.34-3.67$, and High $=3.68-5$, respectively, while professional application of digital tools was divided into three categories: seldom $=1-2.33$, average $=2.34-3.67$, and always $=3.68-5$.

\section{Findings and Discussion}

Question 1: Are there statistical differences at $(\alpha \leq 0.05)$ between the observed and the predicted values of academics who useldon't use e-learning in teaching courses according to faculty at AHU?

To answer the first question of the study, frequencies of the study sample members' responses were calculated.

Table 4. Results of Chi Square (N=107)

\begin{tabular}{ccccc}
\hline \multirow{2}{*}{ Usage } & \multicolumn{3}{c}{ Faculties } \\
\cline { 3 - 5 } & & Humanities & Sciences & Sum \\
\hline \multirow{2}{*}{ Using } & Observed & 46 & 28 & \multirow{2}{*}{74} \\
& Expected & 40.1 & 33.9 & \\
\multirow{2}{*}{ Not Using } & Observed & 12 & 21 & \multirow{2}{*}{33} \\
& Expected & 17.9 & 15.1 & \\
\hline \multicolumn{2}{c}{ Total } & 58 & 49 & 107
\end{tabular}

When calculating Pearson Chi-Square, the calculated value at $\mathrm{df}=1$ was 6.119 significant $(2$-sided=0.020) which means that the distribution of the observed values are different from the expected value, thus there are statistical differences at $(\alpha \leq 0.05)$ between the observed and the predicted values of academics who useldon't use e-learning in teaching courses according to faculty at AHU. For instance, academic members of the humanities faculties with (46) observed value versus (40.1) of expected value shows that members who use digital technology are more than the ones who do not use digital technologies. On the contrary, the members of sciences faculties who use digital technologies are (57\%) which is less than the percentage of humanities faculties members which is (79\%). Based on these results, it can be concluded that the academic members of humanities faculties who use e-learning are more than expected, use e-learning are less than expected, while the members of sciences faculties use e-learning are less than expected and the ones who do not use e-learning are more than expected (Figure 3) 


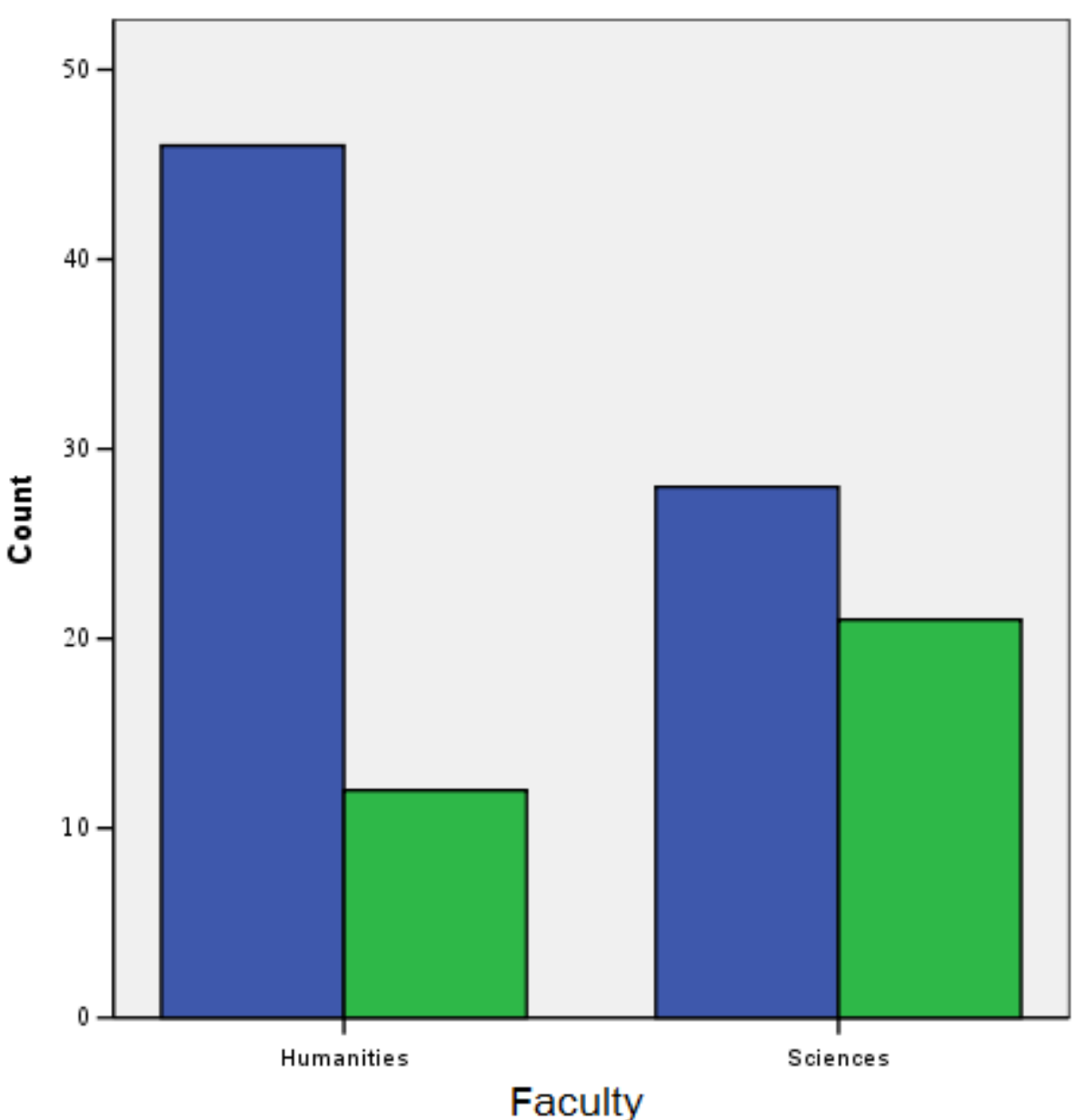

\section{Using e-learning}

$\square$ Yes

$\square$ No

Figure 3. UsinglNot using e-learning

Question 2: What is the degree of AHU academics' professional competence, attitudes, and professional application of digital technologies?

To answer the second question of the study, means and standard deviations of the study sample members' responses were calculated.

Table 5. Results of one sample t- $(\mathrm{N}=107 . \mathrm{Df}=106)$

\begin{tabular}{ccccccc}
\hline Sections & Mean & SD & Rank & T value & Sig & Rank \\
\hline Professional Competence & 3.55 & 1.20 & Average & 10.487 & $.000(\mathrm{a})$ & Average \\
Professional Attitudes & 3.25 & 0.90 & & 10.541 & $.000(\mathrm{a})$ & \\
Professional Application of Digital Tools & 3.23 & 0.87 & & 10.756 & $.000(\mathrm{a})$ &
\end{tabular}

There were observed differences between the degree of academics' professional competence, professional attitudes, and professional application of digital tools, and the crucial score (2.33) which represents the upper limit of the average degree of competence and attitudes and the seldom degree of application. To examine the significance of the observed differences, the results of One-sample t-test showed that there is a statistical significance at $(\alpha \leq 0.05)$. Therefore, the degree of AHU academics' professional competence and attitudes can be ranked as an average, and professional application of digital technologies can be ranked as seldom. The average degree of competencies and attitudes seems to be constant with the academics seldom degree of using technologies tools, the result was affected by the calculation of the whole sample responses where the ones who have low competencies and attitudes surly do not apply any kind of digital tools, besides (46\%) of the faculty members do not use e-learning in teaching their courses. The following table shows a comparison between the means of members' competencies, attitudes, and 
application of digital tool, while two sample t-test where used to understand the differences between them (Using e-learning=74 and Not using e-learning=33).

Table 6. Results of two sample t-test $(\mathrm{N}=107, \mathrm{Df}=105)$

\begin{tabular}{ccccccc}
\hline \multirow{2}{*}{ Sections } & \multicolumn{2}{c}{ Using e-learning } & \multicolumn{2}{c}{ Not using e-learning } & \multirow{2}{*}{ T value } & \multirow{2}{*}{ Sig } \\
\cline { 2 - 5 } & Mean & SD & Mean & SD & & \\
\hline Professional Competence & 4.26 & 0.51 & 1.93 & 0.54 & 21.424 & $.000(\mathrm{a})$ \\
Professional Attitudes & 3.78 & 0.41 & 2.05 & 0.44 & 19.819 & $.000(\mathrm{a})$ \\
Professional Application of Digital Tools & 3.76 & 0.32 & 2.06 & 0.45 & 22.096 & $.000(\mathrm{a})$ \\
\hline
\end{tabular}

All the means of academic members' responses in competence and attitudes were ranked as High for the ones who use e-learning and Low for the members who do not use e-learning, at the same time, the mean of the members who use e-learning can be ranked as Always in their usage and the ones who do not use e-learning can be ranked as Seldom.

Question 3: Are there statistically significant differences at $(\alpha \leq 5.05)$ between the means of academics' degrees of professional competence, professional attitudes, and professional application of technology tools according to their years of experience?

To answer the third question of the study, means and standard deviations of the academics' responses were calculated as shown in the following table:

Table 7. Means and standard deviations according to years of experience

\begin{tabular}{llllllll}
\hline Years of Experience & & Competence & Rank & Attitudes & Rank & Application & Rank \\
\hline 1-5 years, N=29 & Mean & 3.78 & High & 3.39 & Average & 3.49 & Average \\
& S.D & 0.96 & & 0.83 & & 0.74 & \\
6-10 years, N=45 & Mean & 3.38 & Average & 3.19 & Average & 3.11 & Average \\
& S.D & 1.34 & & 0.98 & & 0.74 & \\
More than 10 years, N=33 & Mean & 3.57 & Average & 3.21 & Average & 3.23 & Average \\
& S.D & 1.18 & & 0.87 & & 0.87 & \\
\hline
\end{tabular}

There were observed differences between the degree of academics' professional competence, professional attitudes, and professional application of digital tools according to their years of experience. In other words, academics with (1-5) years of experience showed a high degree of competence, while other experience categories showed an average degree. However, the degrees of attitudes and application were at average level according to all the categories of the years of experience. The following table shows a comparison between the means of members' competencies, attitudes, and application of digital tools according to years of experience variable:

Table 8. ANOVA summery according to years of experience

\begin{tabular}{ccccccc}
\hline \multicolumn{2}{c}{ Source of Variance } & Sum of Squares & df & Mean Square & F & Sig. \\
\hline \multirow{2}{*}{ Competence } & Between groups & 2.871 & 2 & 1.435 & 0.998 & 0.372 \\
& Within groups & 149.676 & 104 & 1.438 & & \\
\hline \multirow{2}{*}{ Attitudes } & Between groups & 0.822 & 2 & 0.411 & 0.499 & 0.609 \\
& Within groups & 85.667 & 104 & 0.824 & & \\
\hline Application & Between groups & 2.63 & 2 & 1.316 & 1.770 & 0.175 \\
& Within groups & 77.326 & 104 & 0.744 & & \\
\hline
\end{tabular}

The results of the ANOVA analysis reported that there were no statistically significant differences at ( $\alpha \leq 5.05)$ between the means of academics' competence, attitudes, and application of digital technologies according to the years of experience.

This result can be explained by the fact that years of experience variable does not influence academics' competence, attitudes, and application of digital technology tools. Hence, new academics are more familiar with mew technologies, while experienced academics are more comfortable with traditional methodologies in competence. 
Since all academics are in average level, then it is very obvious that this result is related to AHU demands of International Computer Licensee for promoting academics.

Question 4: Are there statistically significant differences at $(\alpha \leq 5.05)$ between the means of academics' degrees of professional competence, professional attitudes, and professional application of technology tools according to their academic rank?

To answer the third question of the study, means and standard deviations of the academics' responses were calculate as shown in the following table:

Table 9. Means and standard deviations according to academic rank

\begin{tabular}{cccccccc}
\hline Academic rank & & Competence & Rank & Attitudes & Rank & Application & Rank \\
\hline Instructor, N=31 & Mean & 3.87 & High & 3.41 & Average & 3.4148 & Average \\
& S.D & 1.02 & & 0.70 & & 0.71 & \\
\hline Assistant professor, N=34 & Mean & 3.41 & Average & 3.11 & Average & 3.16 & Average \\
& S.D & 1.25 & & 0.96 & & 0.91 & \\
\hline Associated Professor, N=31 & Mean & 3.46 & Average & 3.30 & Average & 3.10 & Average \\
& S.D & 1.13 & & 0.96 & & 0.86 & \\
\hline Professor, N=11 & Mean & 3.29 & Average & 3.11 & Average & 3.14 & Average \\
& S.D & 1.63 & & 1.12 & & 1.11 & \\
\hline
\end{tabular}

There were apparent differences between the means of academics' competence, attitudes, and digital technology tools applications according to their ranks. To examine the significance of these differences, ANOVA was used.

Table 10. ANOVA summery according to academics rank

\begin{tabular}{ccccccc}
\hline \multicolumn{2}{c}{ Source of Variance } & Sum of Squares & df & Mean Square & F & Sig. \\
\hline \multirow{2}{*}{ Competence } & Between groups & 4.842 & 3 & 1.614 & 1.126 & 0.342 \\
& Within groups & 147.604 & 103 & 1.433 & & \\
\hline \multirow{2}{*}{ Attitudes } & Between groups & 1.695 & 3 & 0.565 & 0.686 & 0.562 \\
& Within groups & 84.793 & 103 & 0.823 & & \\
\hline Application & Between groups & 2.796 & 3 & 0.932 & 1.244 & 0.298 \\
& Within groups & 77.162 & 103 & 0.749 & & \\
\hline
\end{tabular}

The results of the ANOVA analysis reported that there were no statistically significant differences at $(\alpha \leq 5.05)$ between the means of academics' degrees. This result can be justified by the fact that years of experience do not influence academics' competence, attitudes, and application of digital tools. Hence, new instructors who hold master degrees recorded a higher degree but without any statistical significance. So it can be said that there are no statistically significant differences at $(\alpha \leq 5.05)$ between the means of academics' degrees of professional competence, professional attitudes, and professional application of technology tools according to their academic rank.

Question 5: Is it possible to predict the degree of academics' digital technologies usage in teaching through the degree of professional competence and attitudes at AHU?

In order to answer the third question of measuring the relationship between the degrees of professional competencelattitudes of academics and the degree of academics' digital technologies usage, the multiple linear regression analysis was used by the 'Enter' method through entering all the independent variables in the linear regression equation. Table 4 summarizes the results of the regression analysis:

Table 11. Summary of Multi Regression Results (Constance=.476)

\begin{tabular}{cccccccccc}
\hline Dependent Variable & $\mathrm{R}$ & $\mathrm{R} 2$ & $\mathrm{~F}$ & $\mathrm{df}$ & $\mathrm{Sig}$ & $\begin{array}{c}\text { Independent } \\
\text { Variable }\end{array}$ & $\mathrm{B}$ & $\mathrm{T}$ & $\mathrm{Sig}$ \\
\hline $\begin{array}{c}\text { Professional } \\
\text { Application }\end{array}$ & .925 & .856 & 309.659 & 3 & $.000(\mathrm{a})$ & & & 3.898 & $.000(\mathrm{a})$ \\
of Digital Tools & & & & 104 & & Competence & .376 & 4.501 & $.000(\mathrm{a})$ \\
& & & & & & Attitudes & .573 & 6.849 & $.000(\mathrm{a})$ \\
\hline
\end{tabular}


It was noted from the table that the values of the correlation coefficient were $(R=0.925)$, while $\left(R^{2}=0.856\right)$ and the Adjusted $\mathrm{R}^{2}$ was $(0.853)$, meaning that the independent explanatory variables (professional competence and professional attitudes) of digital technologies could explain almost (85\%) of the variables in (the degree of applying digital technologies) and the rest $(15 \%)$ was attributed to other factors. The following histogram shows the linear distribution between all the variables:

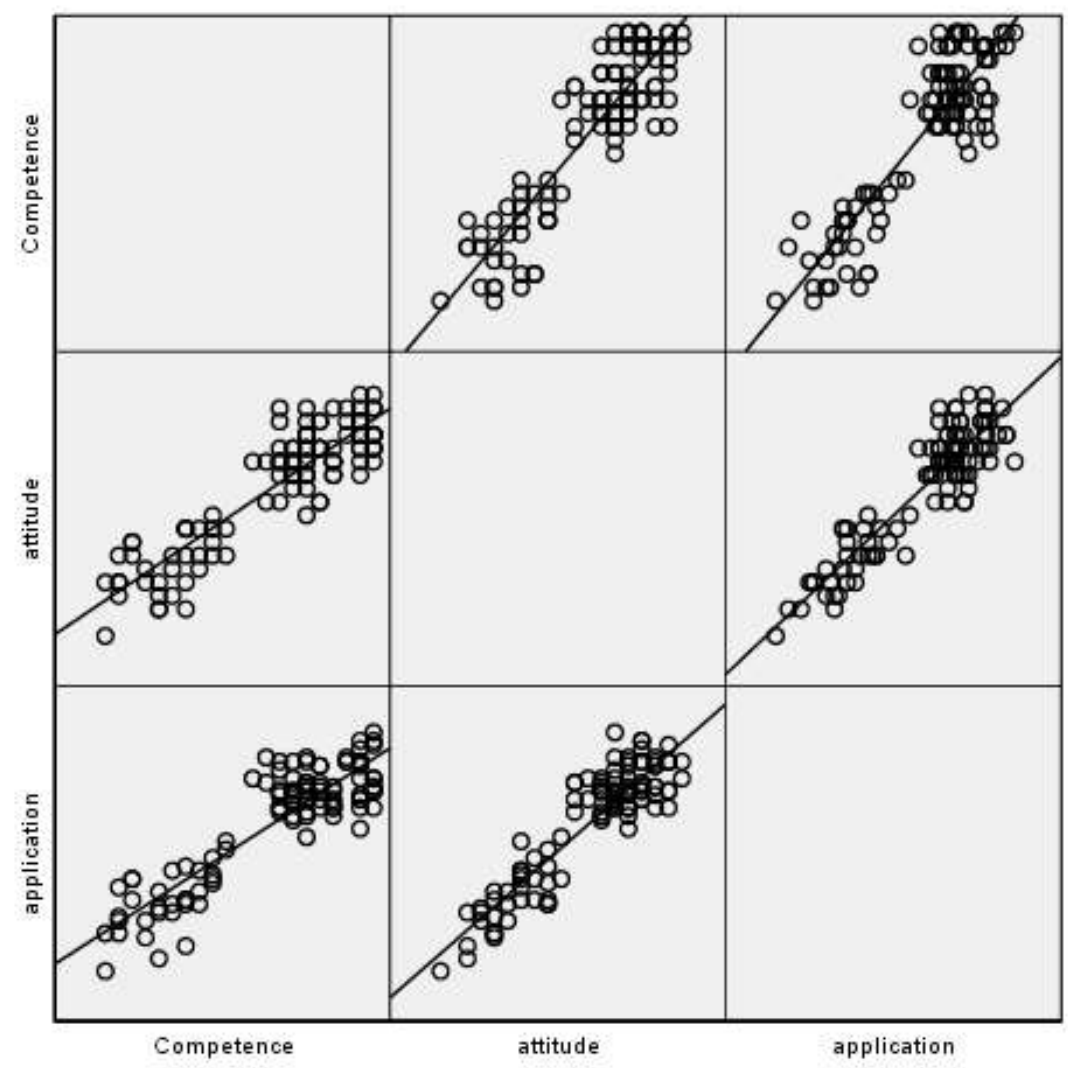

Figure 4. linear distribution between variables

As observed from the analysis of ANOVA, the value $(\mathrm{F}=309.659)$ calculated from the sample is statistically significant at the significance level $(\alpha \leq 0.05)$, which confirms the high explanatory power of the multiple linear regression model. It is also concluded from Table 4 that the independent variables (professional competence and professional attitudes) were statistically significant according to t-test at the significance level $(\alpha \leq 0.05)$.

Based on the results of the regression analysis, the degree of achieving professional application of digital tools usage can be predicted through the degree of professional competence and professional attitudes of the academics in AHU. Linear regression equations were calculated using the Unstandardized Coefficient Beta of the organizational excellence equation at AHU:

Academics' Professional Application of Digital Tools (usage) in AHU $=0.476+(0.273 *$ Competence $)+$ (0.551*Attitudes)

It can be noted from this result that it is possible to predict the degree of professional application of digital tools usage through the degree of professional competence and professional attitudes of the academics in AHU. The competencies that academics gain in addition to their attitudes towards the use of digital technologies in their teaching have a clear and effective role in applying and using technologies tool by improving the quality of teaching performance at the university through the use of efficient, affective and fast digital ways in presenting the content they teach and improving the students understanding. 


\section{Conclusion and Recommendations}

The study revealed that academics have an average degree of competence, attitudes, and application of digital technology tools in teaching at AHU, along with the possibility of predicting the degree of academics' digital technologies usage in teaching through identifying the degree of professional competence and attitudes. We think that it is very important that universities should give a lot of attention to train academics and give them a better opportunity to gain e-learning competencies that help facilitate their ways of teaching. This will be helpful for creating positive attitudes towards digital technologies. Connecting those competences with the academics needs of promotion is an effective way to make them work on developing their skills. In the light of the results achieved, we provide some recommendations that might be helpful to the usage of digital technologies in higher education. It is first recommended that universities should arrange continuous training programs for faculties' members to inform them with the latest digital tools that could be very helpful in teaching students so that they stay up-to-date with new digital tools.

\section{References}

Al-Atyat, Khalid., \& Jwaifell, Mustafa. (2014). Information Literacy among Jordanian Teachers: Case of Madaba. Journal of Education and Practice, 5(28), 102-111.

Al Doghmi, A., Al-Shalabi, H., Jwaifell, M. , Andraws, S., Awajan, A., \& Alrabea, A. I.(2013). The academic use of social networks among university students in Jordan. International Journal of Computer Science Issues, 10(5), 134-141.

Argyris, C. (1992). On Organizational Learning. Cambridge, Massachusetts: Blackwell Publisher.

Bani Abdelrahman, Jwaifell \& El-Subhieen, (2014). Information Literacy: Study of Incoming First-year Undergraduates Students who major in English Language at Al- Hussein Bin Talal University. Journal of Education and Practice, 5(18), 152-167.

Jwaifell, M., Al-Shalabi, H., Andraws, S., Awajan, A., \& Alrabea, A. (2013). The intensity of social networks group use among the students of Jordanian universities. Global Journal of Computer Science and Technology Network, Web \& Security, 13(2), 1-8.

Jwaifell, M., \& Gasaymeh, A. (2013). Using the diffusion of innovation theory to explain the degree of English teachers' adoption of interactive whiteboards in the modern systems school in Jordan: A case study. Contemporary Educational Technology, 4(2), 138

Littlejohn, A., Beetham, H., \& McGill, L. (2011). Learning at the digital frontier: a review of digital literacy in theory and practice. Journal of Computer Assisted Learning, 28(6) pp. 547-556. https://doi.org/10.1111/j.1365-2729.2011.00474.x

Madsen, S. S., Thorvaldsen, S., \& Archard, S. (2018). Teacher educators' perceptions of working with digital technologies. Nordic Journal of Digital Literacy, 13(3), 177-196. https://doi.org/10.18261/issn.1891-943x-2018-03-04

Swidan, A., Al-Shalabi, H., Jwaifell, M., Awajan, A., \& Alrabea, A. (2013). The intensity and the factors affecting the use of social network sites among the students of Jordanian universities. International Journal of Computer Science Issues, 10(1), 492-498.

Waswas, Dima., \& Jwaifell, Mustafa. (2019). The Role of Universities' Electronic Management in Achieving Organizational Excellence: Example of Al Hussein Bin Talal University. World Journal of Education, 9(3), 53-66. https://doi.org/10.5430/wje.v9n3p53 